\title{
Energy Management of Stand-Alone Hydrokinetic Power Supply System with Battery Energy Storage for Rural Electrification
}

\author{
Thin Thin Lwin ${ }^{1}$ Wunna Swe ${ }^{2}$ and Hnin Wah ${ }^{3}$ \\ ${ }^{1-2}$ Electrical Power Engineering Department, Mandalay Technological University, Myanmar \\ ${ }^{3}$ Electrical Power Engineering Department, Technological University (Pkokku), Myanmar
}

\begin{abstract}
In this paper, optimal energy management for a stand-alone hydrokinetic power supply system with a battery storage system is proposed to sufficiently explore hydrokinetic energy for customers at the demand side. The management of power flow aims to optimal energy supply subject to a number of constraints, such as power balance, hydrokinetic power output, and battery capacity. The hydrokinetic turbine is connected with permanent magnet synchronous generator (PMSG), power electronic devices and battery bank. The battery bank is used to store the surplus of energy when the load demand is low and discharges again the stored energy to the load when hydrokinetic power is not sufficient to supply the load. The proposed system can meet the load for every hour of the days without interruption. The average daily load requirement and available hydrokinetic power are calculated for three seasons. In this research, the average daily load requirement of the summer season is chosen because it is the highest in energy consumption from three seasons. The simulation results show that the management of the system is satisfied between available hydrokinetic power and load demand.
\end{abstract}

KeyWords: Stand-alone Hydrokinetic Power Supply System, Battery Storage, Hydrokinetic Turbine, PMSG and Power Electronic Devices.

\section{INTRODUCTION}

In energy production have become more and more focused on using renewable energy resources such as wind, solar, hydro, biomass and geothermal for rural electrification. Among them, hydropower is by far the main source of electricity in Myanmar, accounting for around $57 \%$ of both capacity mix and annual production. Hydrokinetic vitality change includes the use of the kinetic vitality of streams, streams, tidal currents and flows or other man-made conduits for generation of electric power without seizing or redirecting the progression of the water asset. Unlike traditional hydropower which uses the potential energy possessed by a body of water because of its height ('head'), hydrokinetic devices employ the available energy in the velocity of a stream to turn turbines [1].

The problem statement of this paper is that the load center of non-electrified villages is located far away from the substation and the national grid. The need of reasonable and reliable electricity is very much necessary to improve remote rural areas in developing countries [2]. In these regions, electric power is provided by various options. One is for extending the transmission network of existing system, and receiving power from a distant location. However this is not possible to use practice because of high price transportation lines, their losses, and stability issue that may occur during long range power transmission [3]. The other principle weaknesses of the HKT framework just as of other sustainable power source advances are their asset ward yield powers and their solid dependence on climate and climatic conditions. Therefore, they cannot continuously match the fluctuating load energy requirement each and every time. The battery operation limits depending on the interaction between the daily variation of HKT source and the dissimilarity of load demand pattern.

The difference between renewable power generation and load demand are main challenges. From the demand side management (DSM) point of view, energy from the renewable source can be stored when the generation is higher than the demand or discharged when the generation is lower than demand.

In this paper, for demand assessment, the Makyiyay village in Myanmar is selected, which located at 22.02 north latitude and 96.56 east longitude in the Naungkhyo Township, Northern Shan State in Myanmar. And it is also near Dokhtawaddy river which has significant water flow. In this case, a stand-alone system is composed hydrokinetic turbine, battery and converter systems. Based on this evaluation setup, the daily and monthly load profiles for the household data from the village are derived. And also 
the daily and monthly water velocity profiles are obtained from the climate data. Then, the advantages of the proposed system are analyzed power balance condition through simulations using the MATLAB/SIMULINK.

$\begin{array}{ll}\text { LIST OF ABBREVIATIONS } \\ \text { AC-DC } & \text { Alternating Current-Direct Current Converter } \\ \text { DC-DC } & \text { Direct Current-Direct Current Converter } \\ \text { HKT } & \text { Hydrokinetic Turbine } \\ \text { HTS } & \text { Hydrokinetic Turbine System } \\ \text { HKP } & \text { Hydrokinetic Power } \\ \text { IGBT } & \text { Insulated-Gate Bipolar Transistor } \\ \text { LC } & \text { Inductor and Capacitor Filter } \\ \text { PMSG } & \text { Permanent Magnet Synchronous Generator } \\ \text { PWM } & \text { Pulse Width Modulation } \\ \text { SOC } & \text { State of Charge }\end{array}$

\section{DEMAND SIDE ASSESSMENT}

In this paper, for the purpose of evaluation, the Makyiyay village in Myanmar is selected, which located at 22.02 north latitude and 96.56 east longitude in the Naungkhyo Township, Northern Shan State in Myanmar. Based on this evaluation setup, primary data on energy requirement were obtained by structure interview from stakeholders in the village like village executive officer, school leaders, religious leaders and other villagers. The daily and monthly load profiles for the household data from the village are derived. The electricity loads are divided by two groups which are residences and communal facilities. The residences group consists of 35 households in the low-, medium-, and high-income ranges. The electricity demand in the low income range is limited to the requirements for lighting and TV, and the annual growth rate of electricity consumption is small. The households in the medium-income range may additionally use electric fans, and their annual growth rate of electricity consumption is increasing rapidly. The households in the high-income range may use refrigerators. The communal facilities include schools, monastery, rural health clinic, and street lighting. And then, there are divided into three seasons such as summer season from February to May, rainy season from June to September and winter season from October to January. Although all electric loads are used in summer, electric fan load is reduced in rainy and winter. The power consumption of each component is estimated by assuming the hourly usage pattern of the appliances for each load component. This is presented in Table 1.1.

Table 1.1. Load demand for the Makyiyay Village

\begin{tabular}{|c|c|c|c|c|c|}
\hline \multirow{2}{*}{ Components } & \multirow{2}{*}{ Nos } & \multicolumn{2}{c|}{ Power Consumption (kWh/day) } \\
\cline { 3 - 6 } & & Summer & Rainy & Winter \\
\hline \multirow{3}{*}{ Residence } & Low income & 10 & 65.200 & 65.200 & 65.200 \\
\cline { 2 - 5 } & Medium income & 15 & 161.663 & 154.203 & 149.063 \\
\cline { 2 - 5 } & High income & 10 & 137.274 & 129.814 & 128.874 \\
\hline \multirow{3}{*}{ Communal } & School & 1 & 7.418 & 7.418 & 7.418 \\
\cline { 2 - 6 } & Monastery & 1 & 28.150 & 26.658 & 26.350 \\
\cline { 2 - 6 } & Health Clinic & 1 & 24.478 & 24.478 & 23.518 \\
\cline { 2 - 6 } & Street & 5 & 2.400 & 2.400 & 2.400 \\
\hline \multicolumn{2}{|c|}{ Total Power Consumption } & 426.583 & 410.171 & 402.823 \\
\hline
\end{tabular}

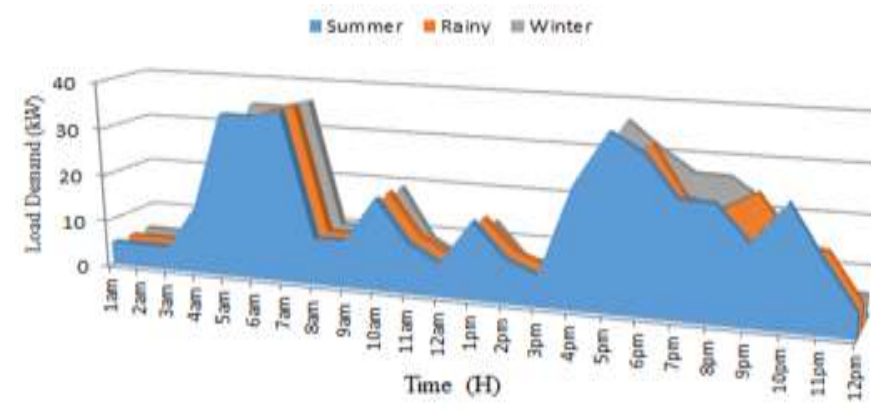

Figure1.1: Daily load profile for the Makyiyay Village

In figure. 1.1, the average, minimum and peak load demands are $17.77 \mathrm{~kW}, 5.03 \mathrm{~kW}$ and $36.104 \mathrm{~kW}$ in summer season, 17.09 $\mathrm{kW}, 5.03 \mathrm{~kW}$ and $35.987 \mathrm{~kW}$ in rainy season. and $16.79 \mathrm{~kW}, 5.03 \mathrm{~kW}$ and $36.104 \mathrm{~kW}$ in winter season. 
International Journal of Advances in Scientific Research and Engineering (ijasre), Vol 5 (11), November-2019

\section{SUPPLY SIDE ASSESSMENT}

The location is a bridge, the Dokhtawaddy bridge acrosses the narrowest of river, which has the maximum local flow velocity as shown in figure.1.2. Therefore, the available kinetic power is the highest in that area.

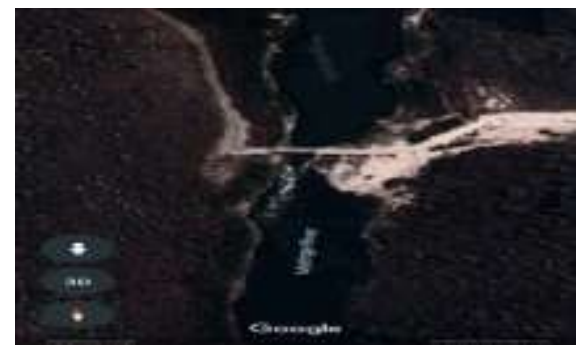

Figure 1.2: Dokhtawaddy Bridge View (Source-Google)

\subsection{Flow Velocity Estimates in the Region}

The water discharge of target site predicted depends on measured data on 20 April 2018 as shown in Table 1.2 and monthly mean records from Department of Meteorology and Hydrology for a period of three years [4]. The predicted monthly discharge presented in Table 1.3 and then illustrated in figure 1.3.

Table 1.2. Measured Data of Proposed Site on 20 April 2018

\begin{tabular}{|c|c|}
\hline Parameters & Specification \\
\hline Velocity & $3.1 \mathrm{~m} / \mathrm{s}$ \\
\hline Depth & $2 \mathrm{~m}$ \\
\hline Width & $33.22 \mathrm{~m}$ \\
\hline Area & $66.44 \mathrm{~m}^{2}$ \\
\hline
\end{tabular}

Table 1.3. Predicted Monthly Discharge $\left(\mathrm{m}^{3} / \mathrm{s}\right)$

\begin{tabular}{|l|c|c|c|}
\hline \multicolumn{1}{|c|}{ Month } & Minimum & Maximum & Average \\
\hline January & 146.320 & 167.40 & 154.22 \\
\hline February & 136.400 & 145.08 & 141.56 \\
\hline March & 124.000 & 137.02 & 129.06 \\
\hline April & 124.000 & 124.00 & 124.00 \\
\hline May & 124.000 & 231.26 & 136.80 \\
\hline June & 201.500 & 241.80 & 226.54 \\
\hline July & 207.080 & 254.20 & 240.02 \\
\hline August & 207.080 & 252.34 & 237.98 \\
\hline September & 201.500 & 251.10 & 235.12 \\
\hline October & 217.620 & 254.20 & 242.62 \\
\hline November & 127.100 & 160.58 & 141.64 \\
\hline December & 133.300 & 252.34 & 177.17 \\
\hline
\end{tabular}

Estimated water velocity using the volumetric flow rate expression [5]:

$\mathrm{Q}=\mathrm{V} \times \mathrm{A} \times$ CorrectionFactor

Where $\mathrm{Q}$ is the volumetric flow rate (discharge), $\mathrm{A}$ is the cross-sectional area and $\mathrm{V}$ is the flow velocity. To estimate the mean velocity, the correction factor varied between 0.60 and 0.85 depending on the watercourse depth and their bottom and riverbank roughness. Respective flow velocities within the focused region are presented in Table 1.4. The maximum and minimum velocities with seasonal variations are $3.5 \mathrm{~m} / \mathrm{s}$ in June of rainy and $3.01 \mathrm{~m} / \mathrm{s}$ in February of summer as shown in figure 1.4. The minimum average velocity is about $3 \mathrm{~m} / \mathrm{s}$ in February of summer.

Table 1.4. Predicted Monthly Velocity $(\mathrm{m} / \mathrm{s})$

\begin{tabular}{|l|c|c|c|}
\hline \multicolumn{1}{|c|}{ Month } & Minimum & Maximum & Average \\
\hline January & 3.05 & 3.20 & 3.10 \\
\hline February & 3.01 & 3.03 & 3.01 \\
\hline March & 3.02 & 3.10 & 3.03 \\
\hline April & 3.05 & 3.10 & 3.10 \\
\hline May & 3.04 & 3.30 & 3.10 \\
\hline June & 3.07 & 3.50 & 3.20 \\
\hline
\end{tabular}


International Journal of Advances in Scientific Research and Engineering (ijasre), Vol 5 (11), November-2019

\begin{tabular}{|l|l|l|l|}
\hline July & 3.07 & 3.40 & 3.10 \\
\hline August & 3.06 & 3.25 & 3.14 \\
\hline September & 3.03 & 3.30 & 3.15 \\
\hline October & 3.05 & 3.20 & 3.11 \\
\hline November & 3.02 & 3.08 & 3.03 \\
\hline December & 3.02 & 3.20 & 3.05 \\
\hline
\end{tabular}

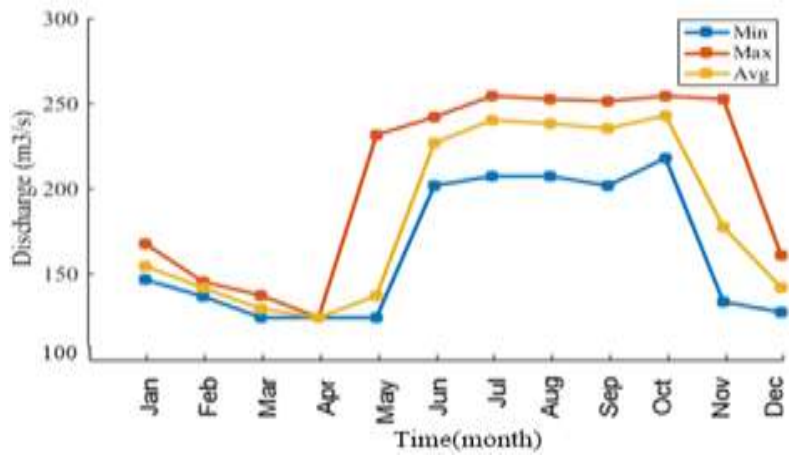

Figure 1.3: Monthly Discharge of Dokhtawaddy River

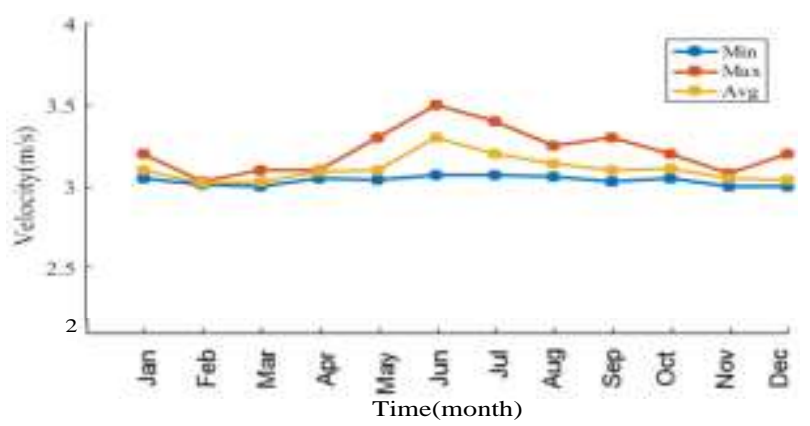

Figure 1.4: Predicted Monthly velocity of Dokhtawaddy River

\subsection{Hydrokinetic Power}

In the proposed system, vertical axis straight blade hydrokinetic turbine is used. The turbine captures a portion of the power in the water that passes it, $P_{\mathrm{m}}$ :

$\mathrm{P}_{\mathrm{m}}=0.5 \rho \mathrm{C}_{\mathrm{p}} \mathrm{A} \mathrm{V}_{\mathrm{w}}^{3}$

Where Pm is the mechanical output power of the hydrokinetic turbine (Watt), $\rho$ is the water density $(\mathrm{kg} / \mathrm{m} 3)$, A is the swept area $(\mathrm{m} 2), \mathrm{C}_{\mathrm{p}}$ is the power coefficient of the hydrokinetic turbine and $\mathrm{V}_{\mathrm{w}}$ is the water speed ( $\left.\mathrm{m} / \mathrm{second}\right)$. The output power of generator can be obtained by multiplying the efficiency of generator and the output power of the hydrokinetic turbine. The estimated hydrokinetic powers that can be harvested in the region are presented in Table 1.5 and Figure 1.5 below. The minimum monthly average powers with seasonal variations are $22.26 \mathrm{~kW}$ in February of summer, $25.27 \mathrm{~kW}$ in August of rainy and $22.68 \mathrm{~kW}$ in November of winter.

Table 1.5. Output Power from the Generator $(\mathrm{kW})$

\begin{tabular}{|c|c|c|c|}
\hline Month & Minimum & Maximum & Average \\
\hline January & 22.97 & 26.54 & 24.18 \\
\hline February & 22.08 & 22.55 & 22.26 \\
\hline March & 21.87 & 24.12 & 22.6 \\
\hline April & 22.97 & 24.12 & 24.05 \\
\hline May & 22.75 & 29.1 & 24.49 \\
\hline June & 23.43 & 34.72 & 29.26 \\
\hline July & 23.43 & 31.83 & 26.57 \\
\hline August & 23.20 & 27.8 & 25.27 \\
\hline September & 22.52 & 29.1 & 25.41 \\
\hline October & 22.97 & 26.54 & 24.55 \\
\hline
\end{tabular}


International Journal of Advances in Scientific Research and Engineering (ijasre), Vol 5 (11), November-2019

\begin{tabular}{|c|c|c|c|}
\hline November & 21.87 & 23.66 & 22.68 \\
\hline December & 21.87 & 26.54 & 22.8 \\
\hline
\end{tabular}

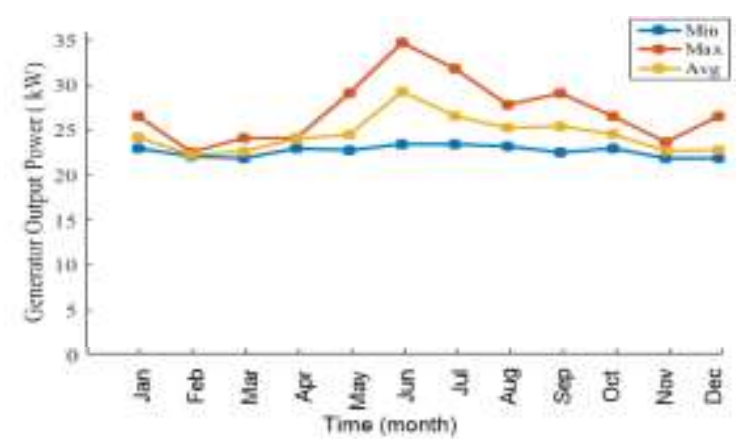

Figure 1.5: Generator output power from target area

The monthly hydrokinetic power of seasonal variations can be sufficient to the monthly load power consumption. This is presented in Table 1.6. For three seasons, the peak load demands are mention in section 2. Therefore, the hydrokinetic power can not sufficiently to supply when load demand exceeds the available power from the system for some hours in day. At this time, hydrokinetic power supply with energy storage systems as battery can supply.

Table 1.6. HKE and Load Power Consumption with Seasonal Variations (kWh/month)

\begin{tabular}{|c|c|c|c|}
\hline Time & Summer (February) & Rainy (August) & Winter (November) \\
\hline HKE (kWh/month) & 14962.752 & 18802.368 & 16336.08 \\
\hline Load Demand (kWh/month) & 11944.324 & 12715.301 & 12084.69 \\
\hline
\end{tabular}

\section{STAND-ALONE HYDROKINETIC ENERGY SUPPLY SYSTEM WITH BATTERY STORAGE}

The hydrokinetic turbine is connected with the permanent magnet synchronous generator to extract electrical energy from river. The power circuit topology of the proposed variable speed stand-alone hydrokinetic energy supply system is shown in figure 1.6.

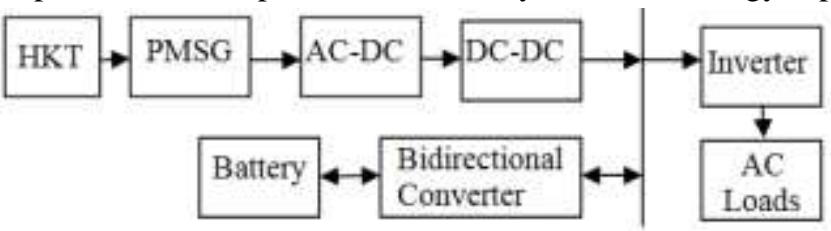

Figure1.6: Schematic diagram of proposed system

The system consists of hydrokinetic turbine, permanent magnet synchronous generator (PMSG), which is directly driven by the hydrokinetic turbine without using a gearbox, a single switch three phase mode rectifier which consists of a three phase diode bridge rectifier, DC-DC boost converter and DC-DC bidirectional converter. A three phase voltage source inverter connected to the load through LC filter.

\subsection{Hydrokinetic Turbine}

Hydrokinetic turbines share numerous likenesses with wind turbines in terms of physical standards of activity, electrical equipment, and variable speed capacity for ideal vitality extraction. Differences relate to the higher density of water, the presence of water surface, turbulence, and predictability of the resources. The first step to design a hydrokinetic turbine system (HTS) is to decide whether to use horizontal turbine system or vertical turbine system. In the proposed system, vertical axis straight blade hydrokinetic turbine is used.

\subsection{Hydrokinetic Turbine Generator}

In order to reduce cost, and to be able to rely on locally-made technology, permanent magnet generator can be used. The magnets allow the speed of generation to be reduced, and lower the cost of the equipment, which itself could be adapted to be a river turbine rotor and ultimately, tested and built [7]. Due to lower generation speed, gearboxes or generators with high number of poles can be used [8].

\subsection{Diode Rectifier}

A rectifier is an electrical device that converts alternating current (AC) to direct current (DC), which flows in only one direction. The three phase full-wave bridge rectifier is one of the most important circuits in high power applications. The rectifier 
can be connected directly to the three phase source. The output voltage of three phase diode rectifier fluctuates between $1.414 \mathrm{~V}_{\mathrm{s}}$ and $1.225 \mathrm{~V}_{\mathrm{s}}$, where $\mathrm{V}_{\mathrm{s}}$ is the RMS values of line voltage.

\subsection{DC-DC Boost Converter}

The input to this converter is an unregulated DC voltage which can be obtained by rectifying an AC voltage source. This unregulated voltage will vary because of the varieties of water speed. In order to control this unregulated DC voltage into a regulated DC output it is needed to use a DC-DC boost converter [9]. The output voltage of boost converter is obtained as

$\mathrm{V}_{\mathrm{O}}=\mathrm{V}_{\mathrm{i}}\left(\frac{1}{1-\mathrm{D}}\right)$

$\mathrm{M}_{V D C}=\frac{\mathrm{V}_{\mathrm{O}}}{\mathrm{V}_{\mathrm{i}}}=\frac{\mathrm{I}_{\mathrm{i}}}{\mathrm{I}_{\mathrm{O}}}=\frac{1}{(1-\mathrm{D})}$

Where, $\mathrm{V}_{\mathrm{o}}$ is output voltage, $\mathrm{V}_{\mathrm{i}}$ is input voltage, $\mathrm{D}$ is duty cycle, and $\mathrm{M}_{\mathrm{VDC}}$ is DC voltage transfer function.

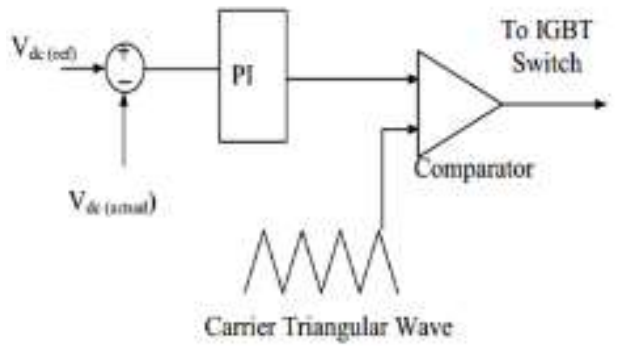

Figure 1.7: DC-DC Boost Converter Controller

The DC-DC boost controller shows in Figure 1.7. The controller of the DC-DC converter can keep up the DC-connect voltage at steady state. The reference voltage, $800 \mathrm{~V}$ will be used to control the DC voltage at the rectifier DC side terminals.

\subsection{DC-DC Bidirectional Converter}

The DC-DC bidirectional buck-boost PWM converter is used to perform the charge and discharge function to the battery bank. The design equations of the buck converter are as follows.

$\mathrm{V}_{\mathbf{O}}=\mathrm{V}_{\mathbf{i}} \mathrm{D}$

$\mathrm{M}_{\mathrm{VDC}}=\frac{\mathrm{V}_{\mathrm{O}}}{\mathrm{V}_{\mathrm{i}}}=\frac{\mathrm{I}_{\mathrm{i}}}{\mathrm{I}_{\mathrm{O}}}=\mathrm{D}$

The function of the controller is that the reference voltage $\left(\mathrm{V}_{\mathrm{dc}-\mathrm{ref}}\right)$ of the converter, $800 \mathrm{~V}$ is compared with the actual dc voltage $\left(\mathrm{V}_{\mathrm{dc} \text {-actual }}\right)$. The error signal is processed through the PI controller. The limiter limits output of PI controller. To generate the duty cycle of the switches $\mathrm{Q}_{1}$ and $\mathrm{Q}_{2}$, the output wave from limiter is compared with the high frequency sawtooth wave by passing comparator. When the switch, $\mathrm{Q}_{1}$ is on, the converter operates the buck function and charges to the battery bank [10-11]. When the switch, $\mathrm{Q}_{2}$ is on, the converter operates as boost mode and discharges to the DC link. The controller of the DC-DC bidirectional converter is shown in figure 1.8 .

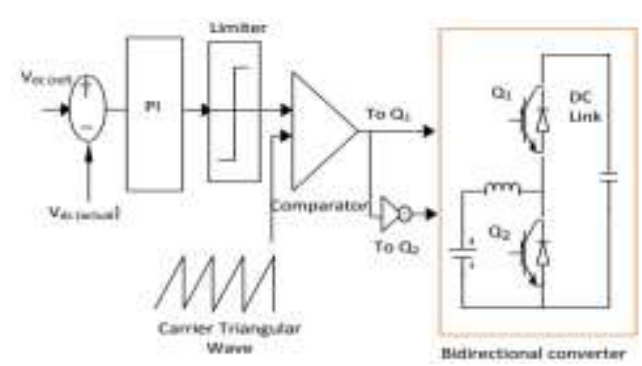

Figure 1 8: DC-DC Bidirectional Converter Controller

\subsection{Load Side Inverter}

The load side inverter, a three phase voltage source inverter, is used as interface between DC link voltage and the load. Voltage source inverter is the most commonly used type. The input DC voltage may be from an independent source such as a battery or may be the output of a controlled rectifier. It consists of six power IGBT switches. The switches are opened and closed 
periodically in the proper sequence to produce the desire output waveform. Load side voltage source inverter can create undesirable high frequency harmonics based on the switching frequency. The voltage source inverter feeds the load through LC filter [12].

\subsection{Sizing of Battery Bank}

System battery size can be calculated by using the following equations. The required daily average energy demand has already been calculated in section 2 .

The estimate energy storage,

$\mathrm{E}_{\mathrm{est}}=\mathrm{E}_{\mathrm{rd}} \times$ the number of autonomy days

The safe energy storage,

$\mathrm{E}_{\mathrm{safe}}=\frac{\text { the estimate energy storage, } \mathrm{E}_{\mathrm{sd}}}{\text { maximum depth of discharge, } \mathrm{D}_{\text {dish }}}$

The total capacity of battery bank in ampere-hours,

$\mathrm{C}_{\mathrm{tb}}=\frac{\text { the safe energy storage, } \mathrm{E}_{\mathrm{safe}}}{\text { the rated dc voltage of one battery, } \mathrm{V}_{\mathrm{b}}}$

And then number of parallel batteries and series batteries will be calculated as follow:

The total number of batteries, $\mathrm{N}_{\mathrm{tb}}=\frac{\mathrm{C}_{\mathrm{tb}}}{\mathrm{C}_{\mathrm{b}}}$

The number of batteries in series, $\mathrm{N}_{\mathrm{sb}}=\frac{\mathrm{V}_{\mathrm{dc}}}{\mathrm{V}_{\mathrm{b}}}$

The number of parallel batteries, $\mathrm{N}_{\mathrm{pb}}=\frac{\mathrm{N}_{\mathrm{tb}}}{\mathrm{N}_{\mathrm{sb}}}$

Therefore, the required battery capacity is $1008 \mathrm{Ah}$. The suitable design with system is Lithium-ion battery model. Its capacity is $300 \mathrm{Ah}, 12 \mathrm{~V}$ and 80 percent discharging. There are 150 numbers of batteries in this system which composed of 3 parallel strings with each including 50 batteries in series. The battery is demonstrated as a nonlinear voltage source whose yield voltage depends on the current as well as on the battery condition state of charge (SOC), which is a nonlinear capacity of the current and time. In this research work, the total installed capacity of the proposed framework is assessed for vitality utilization with occasional varieties which contributes $25 \mathrm{~kW}$ of hydrokinetic turbine and $22.5 \mathrm{~kW}$ of batteries bank.

\section{PROPOSED ALOGORITHM}

The power management strategy should determine the power dispatch between the renewable energy sources, the energy storage devices and the load demand at charging station. 
International Journal of Advances in Scientific Research and Engineering (ijasre), Vol 5 (11), November-2019

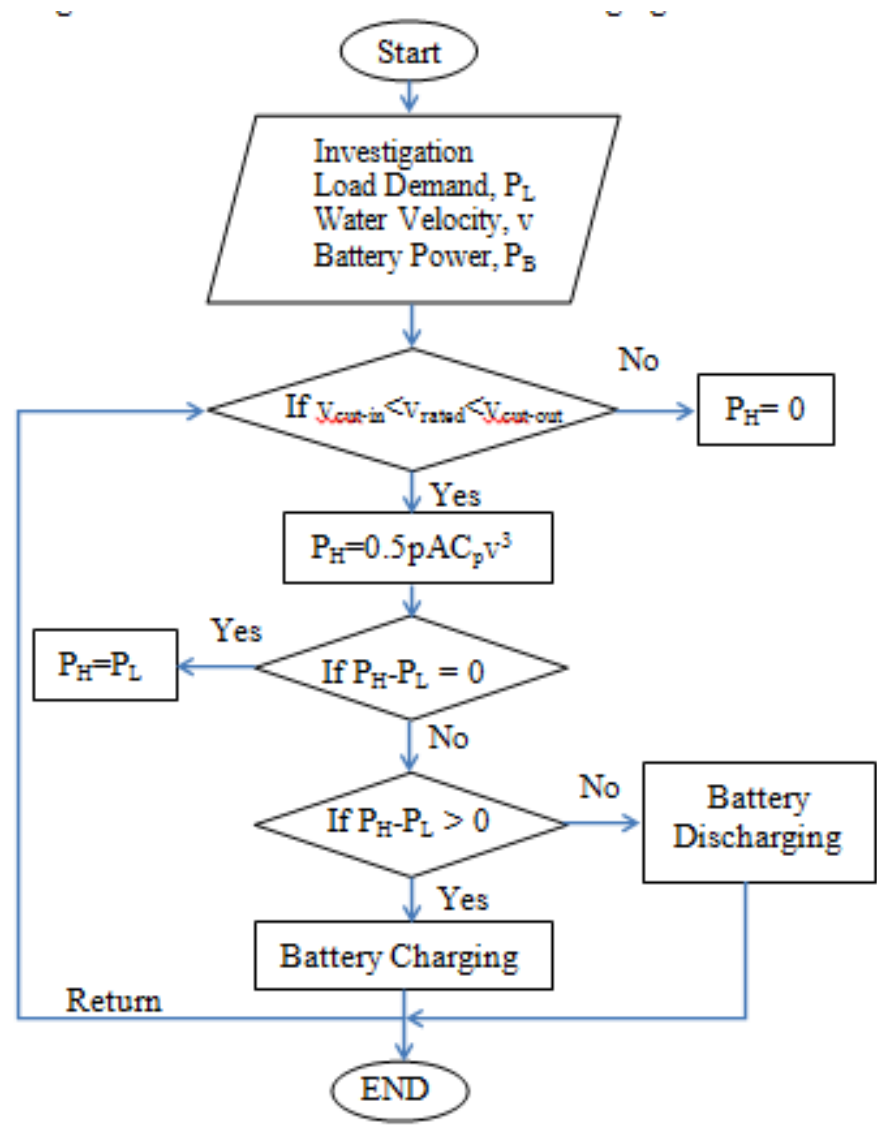

Figure 1.9: Management Algorithm of Proposed System

When the energy generated by hydrokinetic is greater than the energy required by the load, the energy surplus is stored in the batteries and the controller puts the battery in charge condition [13]. When the battery SOC arrives the maximum value, the control system stops the charging process. When the hydrokinetic energy is less than the energy required by the load, the energy deficit is covered by the storage and the controller puts the battery in the discharge condition. Therefore the power balance equality constraint is illustrated in figure 1.9 for demand represented as $\mathrm{P}_{\mathrm{L}}$ at any interval.

\section{RESULTS AND DISCUSSION}

The sizing of HKT and Battery bank are based on a load demand and water velocity of proposed site. The selected load demand reaches a peak demand of $36.106 \mathrm{~kW}$ in summer. Therefore, the proposed system must be able to adequately respond to this demand. The parameters of this system are shown in Table 1.7.

The proposed control strategy of stand-alone hydrokinetic power supply system with battery storage is simulated in MATLAB/SIMULINK as shown in figure 1.10 .

Table 1.7. Parameter of Hydrokinetic Turbine, Generator and Battery

\begin{tabular}{|l|c|c|c|}
\hline Parameter & Symbol & Rating & Unit \\
\hline Rated water speed & $\mathrm{v}_{\text {rated }}$ & 3.0 & $\mathrm{~m} / \mathrm{s}$ \\
\hline Cut-in water speed & $\mathrm{v}_{\text {cut-in }}$ & 1.5 & $\mathrm{~m} / \mathrm{s}$ \\
\hline Cut-out water speed & $\mathrm{v}_{\text {cut-out }}$ & 4.5 & $\mathrm{~m} / \mathrm{s}$ \\
\hline Blade diameter & $\mathrm{D}$ & 3 & $\mathrm{~m}$ \\
\hline Blade height & $\mathrm{H}$ & 1.5 & $\mathrm{~m}$ \\
\hline Power coefficient & $\mathrm{C}_{\mathrm{p}}$ & 0.4 & - \\
\hline Swept area & $\mathrm{A}$ & 4.5 & $\mathrm{~m}^{2}$ \\
\hline Turbine rated speed & $\mathrm{N}$ & 60 & $\mathrm{rpm}$ \\
\hline Generator rated power & $\mathrm{P}$ & 25 & $\mathrm{~kW}$ \\
\hline Frequency & $\mathrm{f}$ & 50 & $\mathrm{~Hz}$ \\
\hline Pole pair & $\mathrm{p}$ & 50 & - \\
\hline Stator phase resistance & $\mathrm{R}_{\mathrm{s}}$ & 1.144 & $\mathrm{ohm}$ \\
\hline Armature Inductance & $\mathrm{L}$ & 0.00448 & $\mathrm{mH}$ \\
\hline
\end{tabular}


International Journal of Advances in Scientific Research and Engineering (ijasre), Vol 5 (11), November-2019

\begin{tabular}{|l|c|c|c|}
\hline $\begin{array}{l}\text { Lithium-ion battery system rated } \\
\text { voltage }\end{array}$ & $\mathrm{V}$ & 600 & $\mathrm{~V}$ \\
\hline Rated capacity & $\mathrm{C}_{\mathrm{b}}$ & 900 & $\mathrm{Ah}$ \\
\hline Initial SOC & $\mathrm{SOC}$ & 80 & $\%$ \\
\hline Cut-off voltage & $\mathrm{V}_{\text {cut-out }}$ & 450 & $\mathrm{~V}$ \\
\hline Full charge voltage & $\mathrm{V}_{\text {full-charge }}$ & 680 & $\mathrm{~V}$ \\
\hline Require battery capacity & $\mathrm{C}_{\mathrm{tb}}$ & 1008 & $\mathrm{Ah}$ \\
\hline Number of parallel batteries & $\mathrm{N}_{\mathrm{pb}}$ & 3 & nos \\
\hline Number of series batteries & $\mathrm{N}_{\mathrm{sb}}$ & 50 & nos \\
\hline Total number of batteries & $\mathrm{N}_{\mathrm{tb}}$ & 150 & nos \\
\hline
\end{tabular}

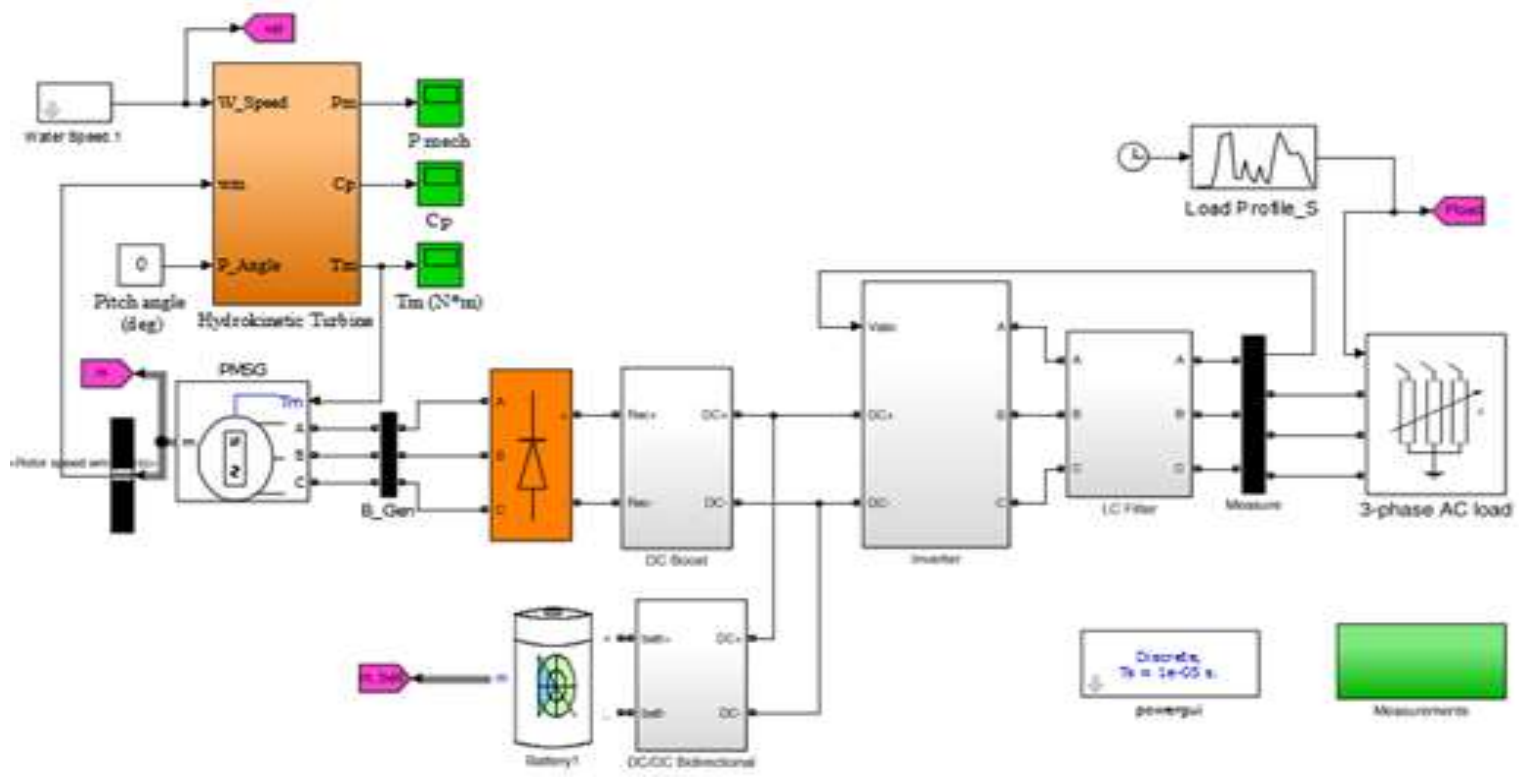

Figure 1.10: Simulation Model of Stand-alone Hydrokinetic Power Supply System with Battery Storage
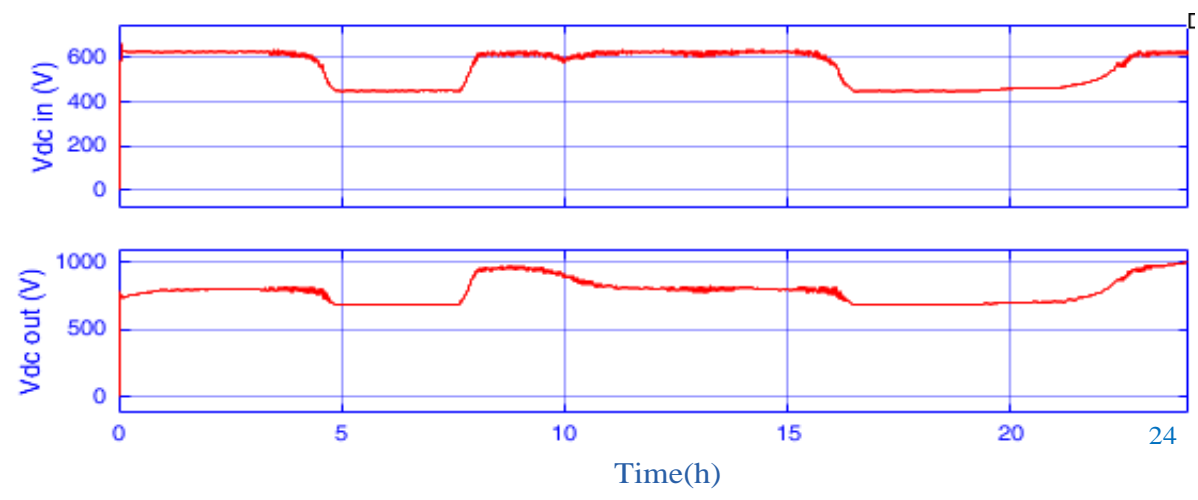

Figure 1.11: DC-link Input and Output Voltages of Proposed System

Figure 1.11 and 1.12 show DC links voltage and current of the stand-alone hydrokinetic system different operation conditions. The initial battery state of charge, $80 \%$ is used in the battery simulation model. The battery state of charge, its current and voltage can be seen as in figure 1.13 (a), (b) and (c) respectively. In figure 1.13 (c), the negative section of curve shows the charging of battery bank, and the positive section shows discharging of battery bank. The battery current is negative value as it is charged and after one second the battery starts discharge to DC the link. 
International Journal of Advances in Scientific Research and Engineering (ijasre), Vol 5 (11), November-2019
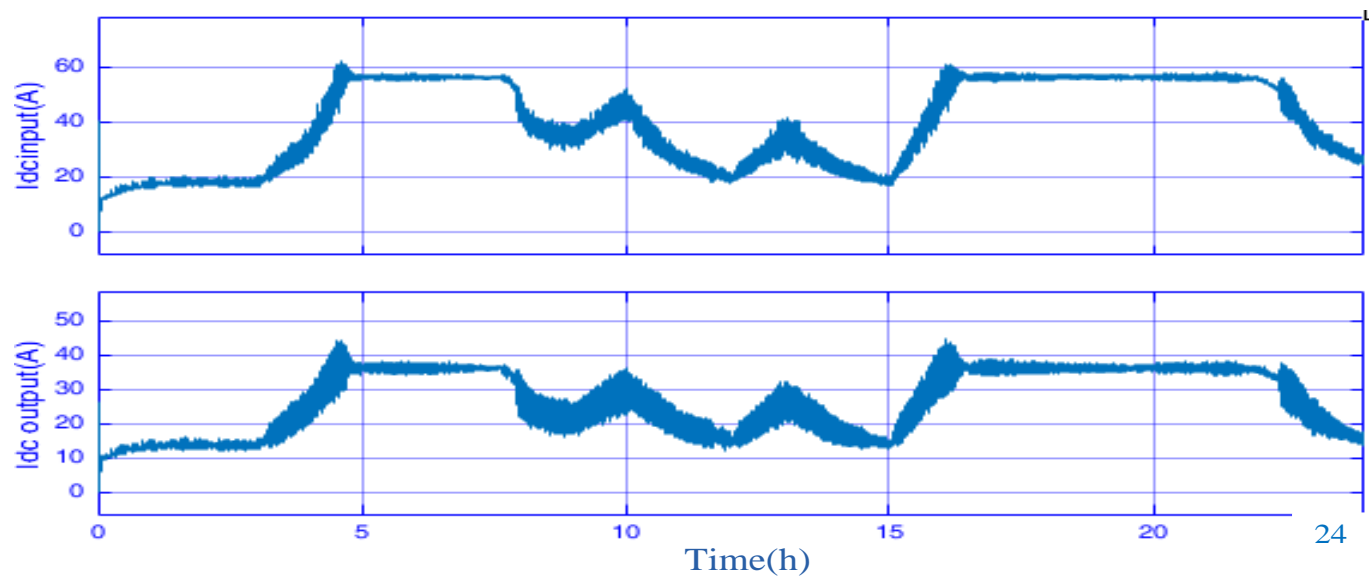

Figure 1.12: DC-link Input and Output Currents of Proposed System

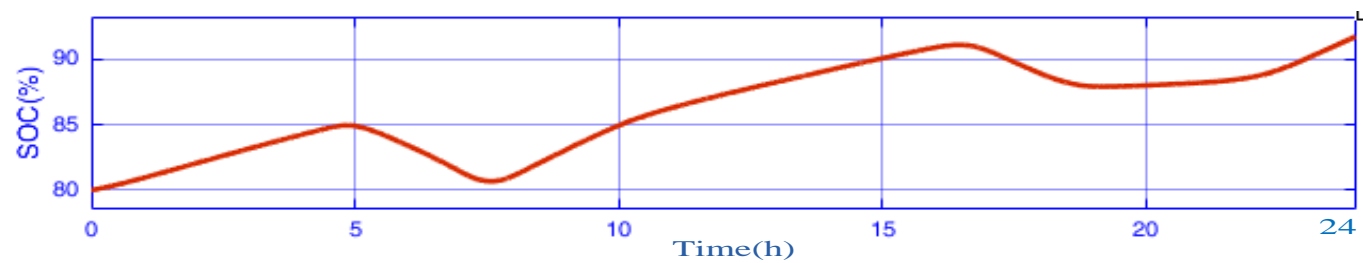

(a)

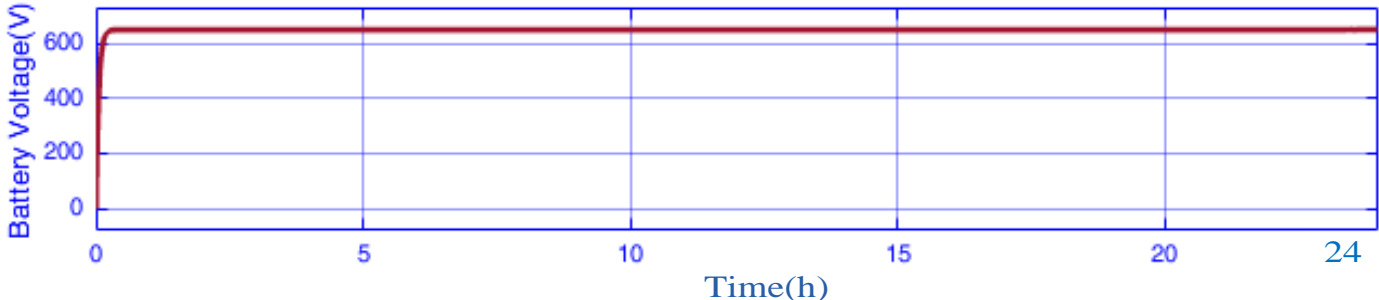

(b)

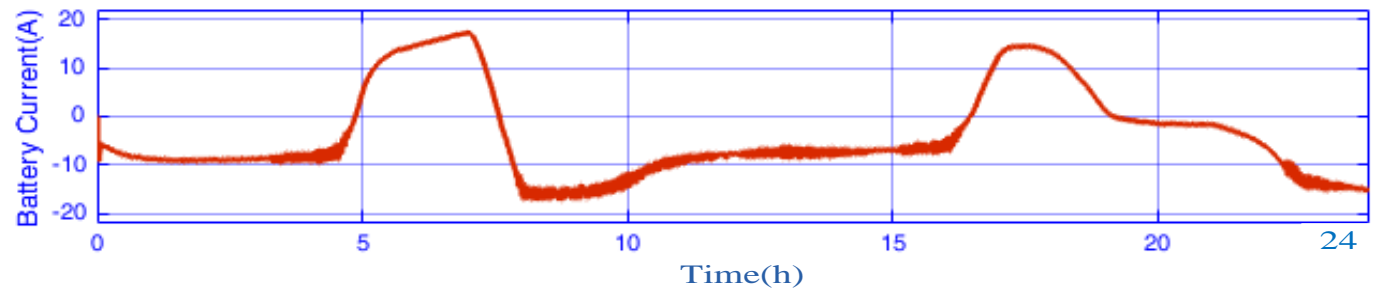

(c)

Figure 1.13: (a) SOC (\%), (b) Voltage (V) and (c) Current (A) of Battery

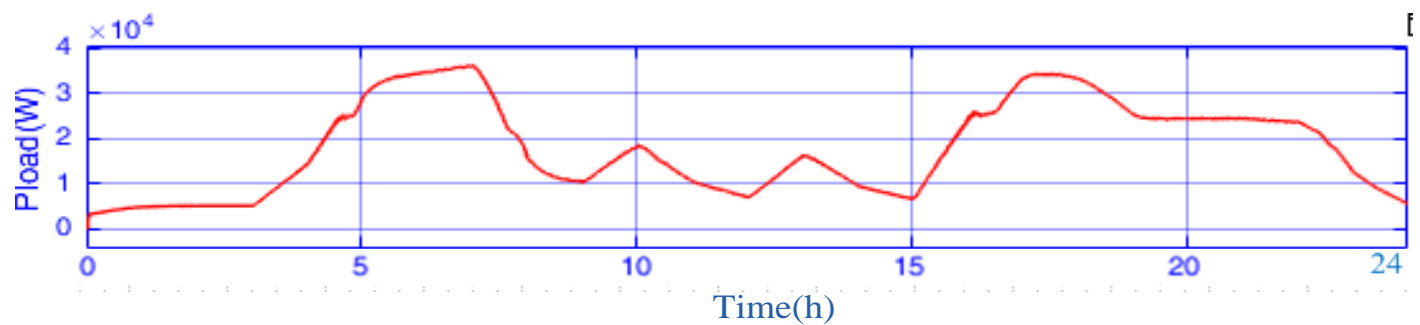

(a)

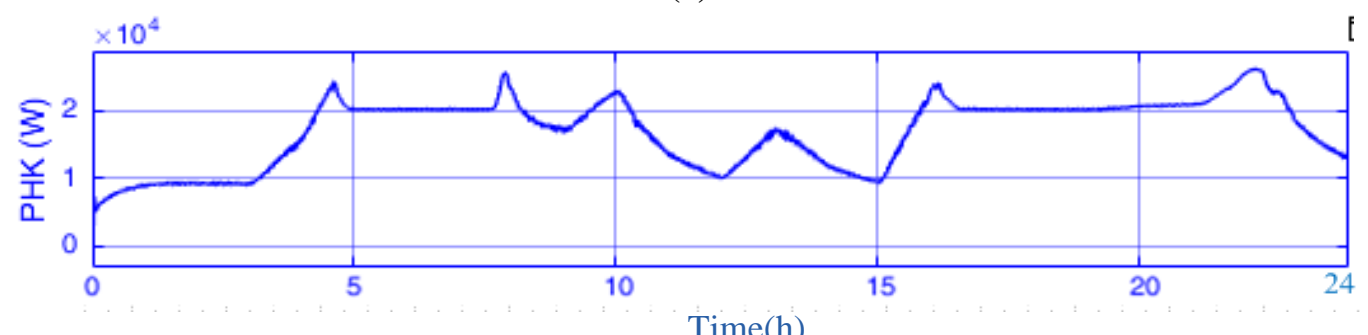


International Journal of Advances in Scientific Research and Engineering (ijasre), Vol 5 (11), November-2019

(b)

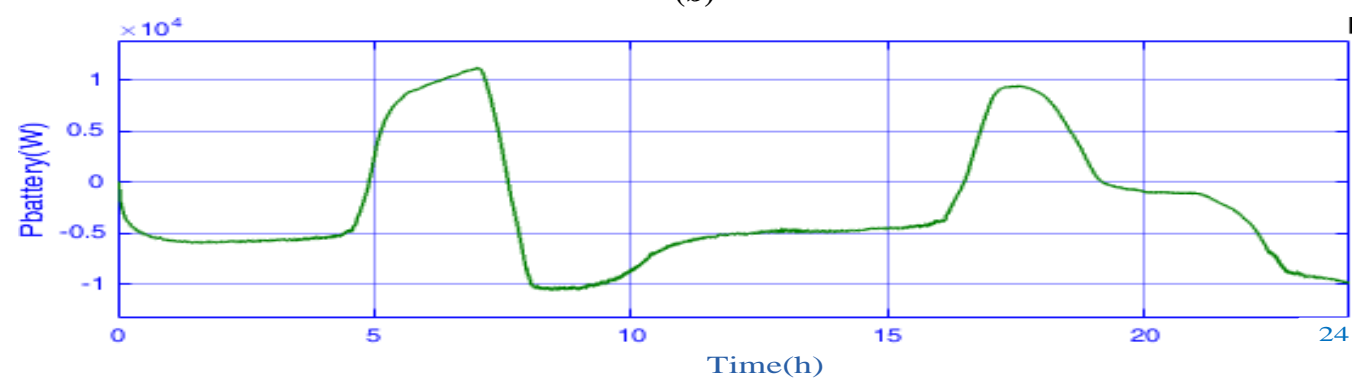

(c)

Figure 1.14: (a) Load Side Power, (b) Power of HKT and (c) Charging and Discharging Power of Battery

The simulation results of load side power, generated hydrokinetic power and charging and discharging power of battery are shown in Figure 1.14:(a), (b) and (c) respectively.
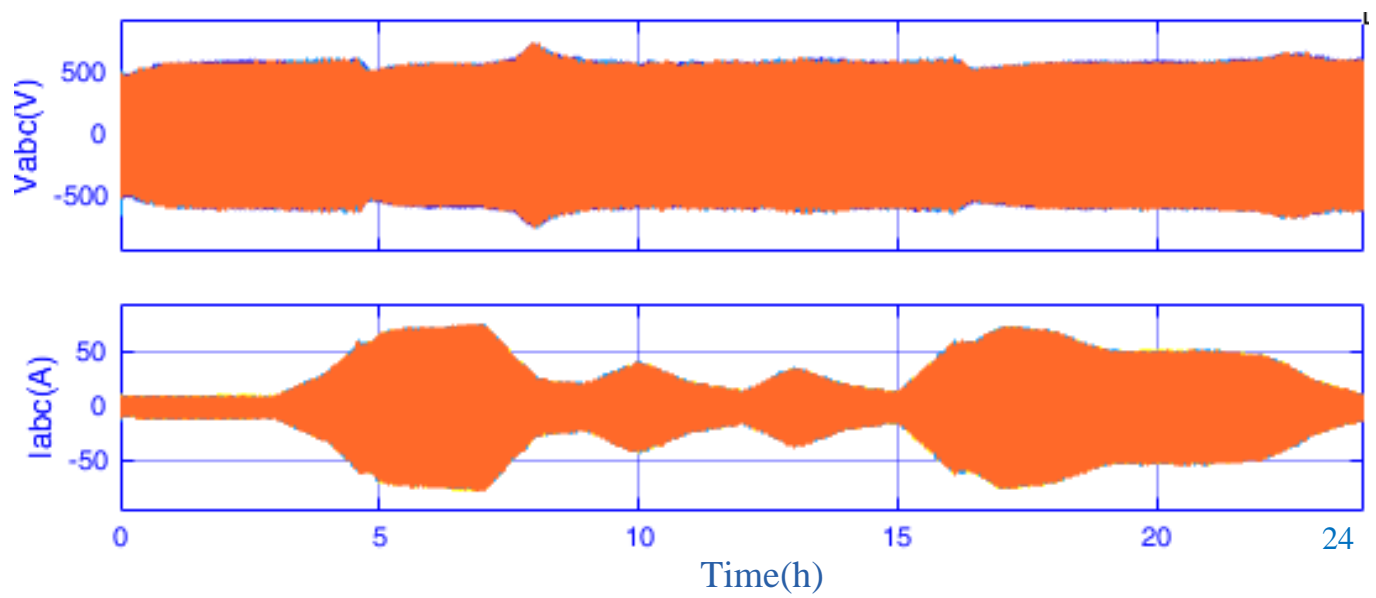

(a)
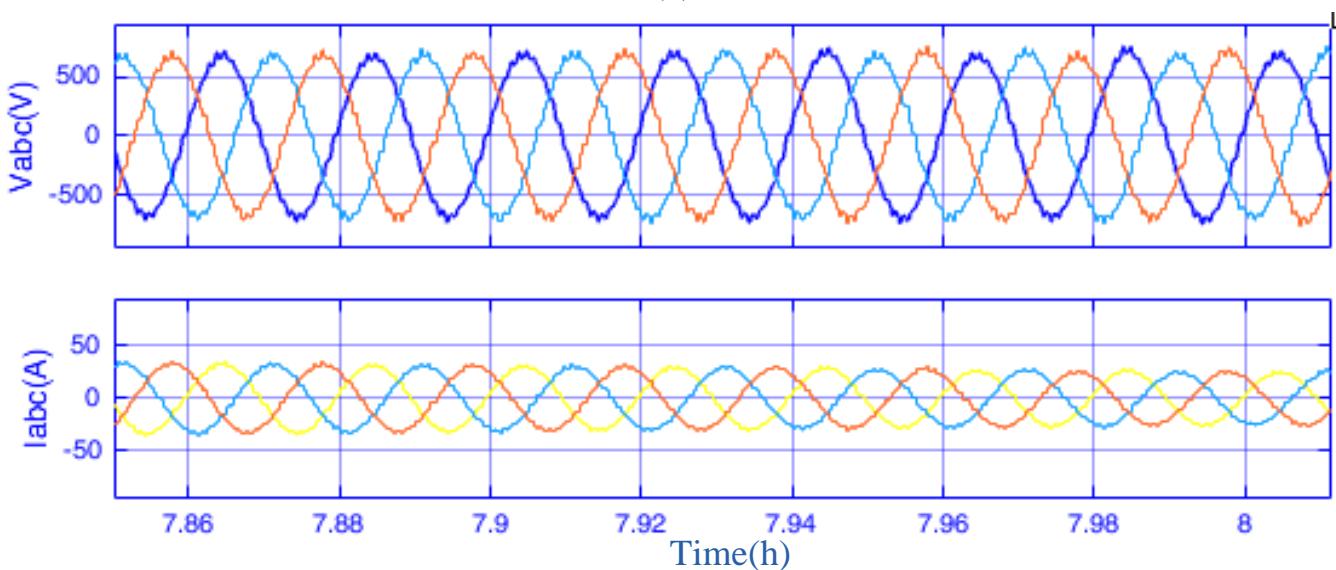

(b)

Figure 1.15: Inverter (a) Output Voltage and Current Throughout the Full Simulation Time (b) Output Voltage and Current at simulation Time 7.86 h to $8.6 \mathrm{~h}$ of the Proposed System

Inverter output voltage and current of the proposed system can be seen in Figure 1.15 and figure 1.16 under different conditions. It can be seen that the load voltage is stable at $400 \mathrm{~V}$ and the load current of the system under different conditions as shown in figure 1.16 . 

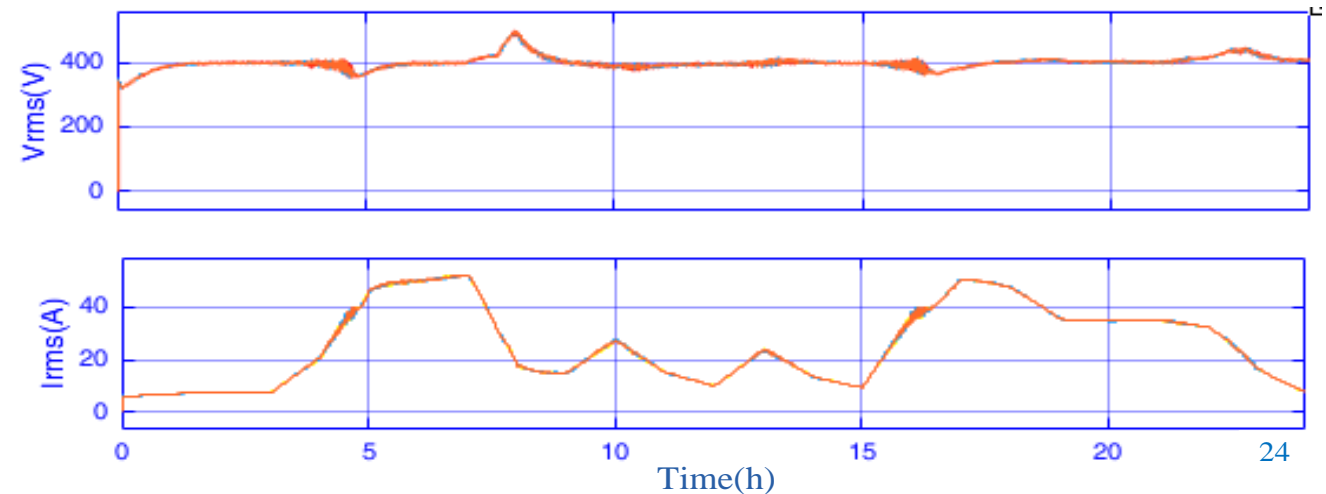

Figure 1.16: Output Line Voltage and Current of the Proposed System

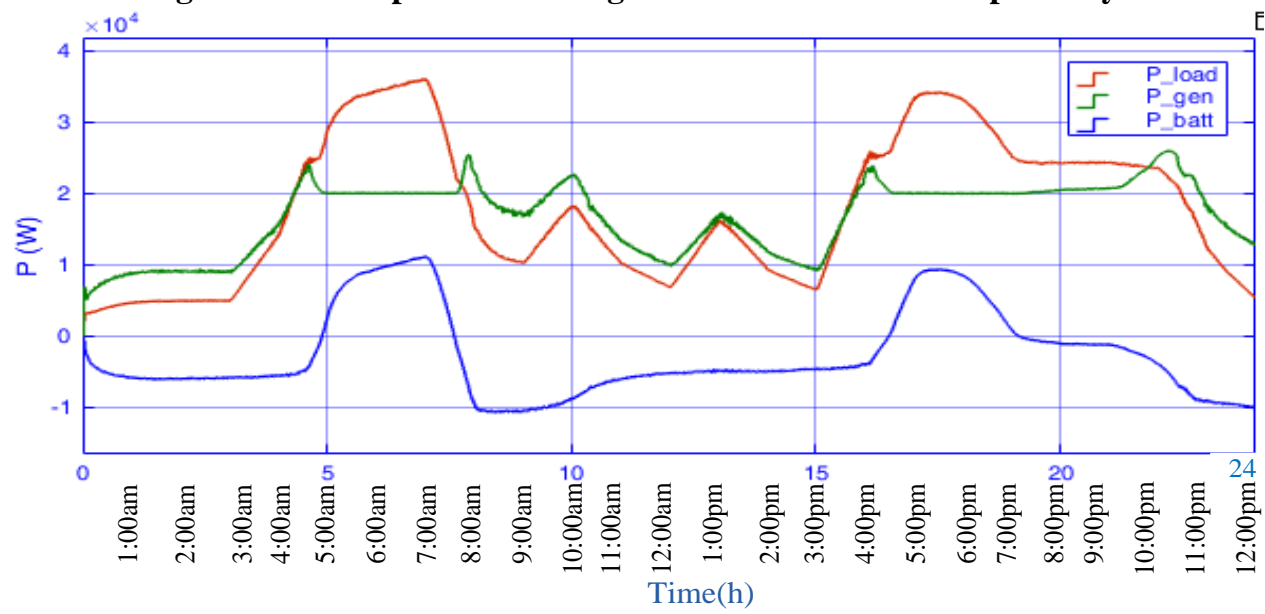

Figure 1.17: Simulation Result of Providing Power of Load, HKP and Battery Storage System

The simulation results of load side power, generated hydrokinetic power and charging and discharging power of battery shown in Fig. 17. From 11:00 pm to 4:30 am and 7:30 am to 3:30 pm, in this durations, hydrokinetic power is not only supplied the load but also charged the battery storage system. On the other hand, from 4:30 am to 7:30 am and 3.30 pm to 11:00pm, during the peak load condition, the majority of the load is supplied by the combination of hydrokinetic power and battery bank. Thus, according to the comparison of hydrokinetic power, load demand and battery bank with seasonal variations, the HKP source as $25 \mathrm{~kW}$ at $3 \mathrm{~m} / \mathrm{s}$ water velocity and 900Ah of battery bank were evaluated.

\section{CONCLUSION}

In this research, the energy management system and design consideration of hydrokinetic power supply with battery storage system are mentioned. The monthly hydrokinetic power of seasonal variations can be sufficient to the monthly load power consumption. The hydrokinetic power is not able sufficiently supplied when load demand exceeds the available power from the system for some hours in day. The battery bank stores the surplus of energy when the load demand is low and discharges again the stored energy to the load when hydrokinetic power is not sufficient to supply the load. The management of the system is satisfied between available hydrokinetic power and desired load demand. In this research work, the total installed capacity of the proposed system is designed by $25 \mathrm{~kW}$ of hydrokinetic turbine and $22.5 \mathrm{~kW}$ of batteries bank for peak load demands with seasonal variations. The further extensions are to implement conditions that the hydrokinetic turbines should be added to the system in order to achieve enough energy for consumers. As seen from the results, the system can be supplied for enough power to consumers who live in Makyiyay village without interruption.

\section{ACKNOWLEDGMENT}

The author would like to express grateful thanks to her supervisor Dr. Wunna Swe, Professor and Head, Department of Electrical Power Engineering and to all her teachers from Mandalay Technological University, for their valuable guidance. The author greatly expresses to her thanks to all persons whom will concern to support in preparing this paper. Finally, the author wishes to express her deepest gratitude to her parents for providing the funding for the large majority of her education.

\section{REFERENCES}

1. L.L. Ladokun et al., "Resource assessment and feasibility study for the generation of hydrokinetic power in the tailwaters of selected hydropower stations in Nigeria", Water Science 32, pp. 338-354, 2018. 
2. Christopher Joshi Hansen and John Bower, “An Economic Evaluation of Small-scale Distributed Electricity Generation Technologies," Oxford Institute for Energy Studies, EL 05, Oct.2003.

3. R.Messenger and J. Ventre, "Photovoltaic Systems Engineering", CRC Press, pp.41-51, 2000.

4. Thin Thin Lwin, Wunna Swe and Lai Lai Wah, "Energy-Balance Control of Stand-Alone Hydrokinetic Power Supply System with Battery Energy Storage for Rural Electrification", Universal Academic Cluster International May Conference, Bangkok, PP 22-38, 16-17 May, 2019.

5. NRC-CHC. Ottawa “Assessment of Canada's Hydrokinetic Power Potential," National Research Council of Canada Canadian Hydraulics Centre, March 2010.

6. M. J. Khan, G. Bhuyan, M. T. Iqbal, and J. E. Quaicoe, "Hydrokinetic energy conversion systems and assessment of horizontal and vertical axis turbines for river and tidal applications: A technology status review," Applied Energy, vol. 86, pp. 1823-1835.

7. Susanto J, Stamp S. Local installation methods for low head pico-hydropower in the Lao PDR. Renewable Energy 2012; 44:439e47.

8. Grabbe M, Yuen K, Goude A, Lalander E, Leijon M. Design of an experimental setup for hydro-kinetic energy conversion. The International Journal on Hydropower \& Dams 2009;16(5):112e6.

9. Hugo Eduardo Mena Lopez, "Maximum Power Tracking Control Scheme for Wind Generator Systems", Dec, 2007.

10. Ahmadi S, Abdi S. Application of the Hybrid Big Bang-Big Crunch algorithm for optimal sizing of a stand-alone hybrid PV/wind/battery system. Sol Energy 2016; 134: 366-374.

11. M.S Behzadi and M. Niasati. 'Comparative performance analysis of a hybrid PV/FC/battery stand-alone system using different power management strategies and sizing approaches', International journal of hydrogen energy. Volume 40 (Issue 1). pp. 538-548, Jan, 2015.

12. Shiladitya Saha, Gaurav Agarwa, Kundan Kumar, "Study and Analysis of Three Phase SPWM Inverter", May, 2012.

13. Ahmadi S, Abdi S. Application of the Hybrid Big Bang-Big Crunch algorithm for optimal sizing of a stand-alone hybrid PV/wind/battery system. Sol Energy 2016; 134: 366-374. 